\title{
Metrics and Indicators to Aid in the Financing of Agricultural Loans to Rural Families: A Systematic Review
}

\author{
By Euclides Alfredo Matusse
}

Abstract- The use of indicators provides several benefits among which the effective evaluation in the financing of agricultural loans to borrowers and also the support to the credit manager and portfolio in making strategic decisions. Despite the relevance of using metrics to aid in the financing of agricultural credit given the diversity of the existing business model, organizations have neglected their practice. Reasons for this fact include: (i) although access to credit is an significant factor in the adoption of agricultural technologies and increased agricultural incomes among rural farmers, are generally not sufficiently mature to make use of measurements or 2) researchers are not yet widely aware of the need for exploratory studies that identifies a mechanism to propose an agricultural credit financing strategy based on indicators through the analysis of a set of metrics. In this context, this article aims to conduct a systematic review to collect evidence on the existence of metrics and indicators that are specific for financing agricultural loans to rural families. The study produced 64 articles selected from the current literature and were not repeated because they were relevant.

Keywords: Ioans, credit, accessibility, metrics, indicators, systematic review.

GJSFR-D Classification: FOR Code: 079999

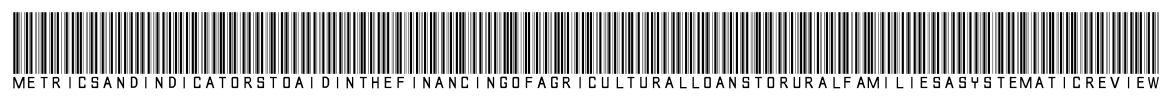

Strictly as per the compliance and regulations of:

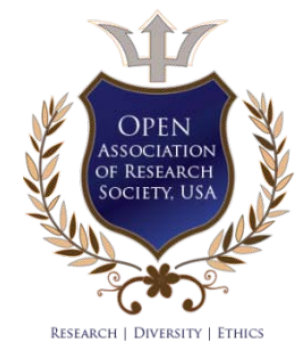

(c) 2019. Euclides Alfredo Matusse. This is a research/review paper, distributed under the terms of the Creative Commons Attribution-Noncommercial 3.0 Unported License http://creativecommons.org/licenses/by-nc/3.0/), permitting all non commercial use, distribution, and reproduction in any medium, provided the original work is properly cited. 


\title{
Metrics and Indicators to Aid in the Financing of Agricultural Loans to Rural Families: A Systematic Review
}

\author{
Euclides Alfredo Matusse
}

\begin{abstract}
The use of indicators provides several benefits among which the effective evaluation in the financing of agricultural loans to borrowers and also the support to the credit manager and portfolio in making strategic decisions. Despite the relevance of using metrics to aid in the financing of agricultural credit given the diversity of the existing business model, organizations have neglected their practice. Reasons for this fact include: (i) although access to credit is an significant factor in the adoption of agricultural technologies and increased agricultural incomes among rural farmers, are generally not sufficiently mature to make use of measurements or 2) researchers are not yet widely aware of the need for exploratory studies that identifies a mechanism to propose an agricultural credit financing strategy based on indicators through the analysis of a set of metrics. In this context, this article aims to conduct a systematic review to collect evidence on the existence of metrics and indicators that are specific for financing agricultural loans to rural families. The study produced 64 articles selected from the current literature and were not repeated because they were relevant. After the initial filter, 42 were pre-selected to identify potential primary studies by reading the title, summary, and conclusion using the PICO method (population, intervention, comparison, and outcome) and a new subset by the reading criterion in depth by the total reading of the article. Those who presented consistent information about metrics and indicators for agricultural credit financing remained. In this second stage (final selection) 18 studies were selected for a detailed comparative analysis.
\end{abstract}

Keywords: Ioans, credit, accessibility, metrics, indicators, systematic review.

\section{INTRODUCTION}

$\mathrm{M}$ icrofinance Institutions (MFIs) play a vital role in supporting the agrarian sector, as well as in rural development by issuing loans to farmers Yara et al. (2019). Microcredit is a product of providing financial services to low-income borrowers, including consumers and independent workers, who traditionally do not have access to banking and related services (Gonzalez-Vega, 2008). This initiative enables several benefits such as adopting technologies, building assets, smoothing consumption, managing risks and increasing incomes among farmers (Omonona et al. 2008; Mosca and Dadá 2014), but also growth of employment and poverty reduction (Soubbotina et al. 2000).

Author: Agribusiness Research Program, Innovation in Information technology LTDA, Mozambique. e-mail: ematusse27@gmail.com
However, to achieve these benefits, it is necessary to implement the rigorous planning, because the risks arising this strategy can affect the viability and sustainability of microcredit institutions due to the characteristics of the loan Onyeagocha et al. (2012).

However, the dynamic nature of the financing of agricultural credit imposes several challenges caused by the accessibility of the loan Khalid Mohamed (2003), capacity for reimbursement and spatial distance between the place of farmers (arable land) in Loan sources Abiodun et al. (2009). These challenges were classified as technical, non-technical, and hybrids illustrated in table VII. The factors are related to determinants of access to credit and reimbursement capacity Adu et al. (2019); non-technical challenges are related to characteristics of borrowers, firms and lenders, and hybrid factors are challenges that relate to delinquency characteristics of reimbursement and institutional factors Allan Mitei et al. (2016).

Faced with these challenges in order to support agricultural credit financing for rural families, we conducted a systematic review of existing solutions in the literature, which allowed us to identify the approaches, models, techniques, methodologies and their particularities. Thus, this article aims to present and analyze the results of this review, considering the technical, non-technical and hybrid aspects of each approach.

The remainder of the work is organized as follows: section 2 presents a characterization of access to agricultural credit financing to the rural family; In step 3 , it describes the methodology of the review and its use; In section 4, the results of the study: maps of the questions and the solutions identified in this literature; Step 5 analyzes and identifies approaches, comparing their characteristics; In section 6 presents the conclusions and finally, 7 discusses the opportunities for future work and bibliographical references.

\section{Access to the Financing of Agricultural Credit the Rural Family}

Microfinance is the provision of a wide range of financial services such as deposits, loans, payment services, money transfers and insurance for poor and low-income families Conroy (2002). This definition have 
to be based on poor customers to have access to highquality service, which include not only agricultural credit, rural credit, but also savings, insurance, and funds transfer.

Although the terms "rural credit ," "agricultural credit" are often used alternately, it is matters to note the subtle differences between them, because there is a logical sequence in the way that credits has to be obtained in financial sectors CGAP (2003). Rural credit refers to credit services in rural areas that target people in all incomes; agricultural credit is likely to finance activities related to agriculture Le Thi Minh (2014).

The financing of agricultural credit remains a challenge categorized into three main areas: inherent characteristics of borrowers such as guarantees, high liquidity interest, lack of insurance and their business, the credit institution and Appropriateness of the loan product to the borrower and, systematic risk of external factors, economic, political and business environment in which the borrower is inserted by Derban et al. (2005).

Looking for a representation that defines the level of financing of agricultural credit, Figure 1 illustrates the scenario (determinants of access to formal and semiformal credit) and the relationship between them, considering the spatial distance between the site of the small Farmers in relation to loan sources (Abiodun et al. 2009, Njoku, 2016). The representation of groups of farmers is composed of members located in cooperatives requesting credit to mitigate the agency's problems, moral risk and adverse selection to replace the requirement of guarantees. In turn, credit demand has an overview of the borrower's business and its determinants, to extract an indicator to direct agricultural credit financing to rural families Matusse (2019).

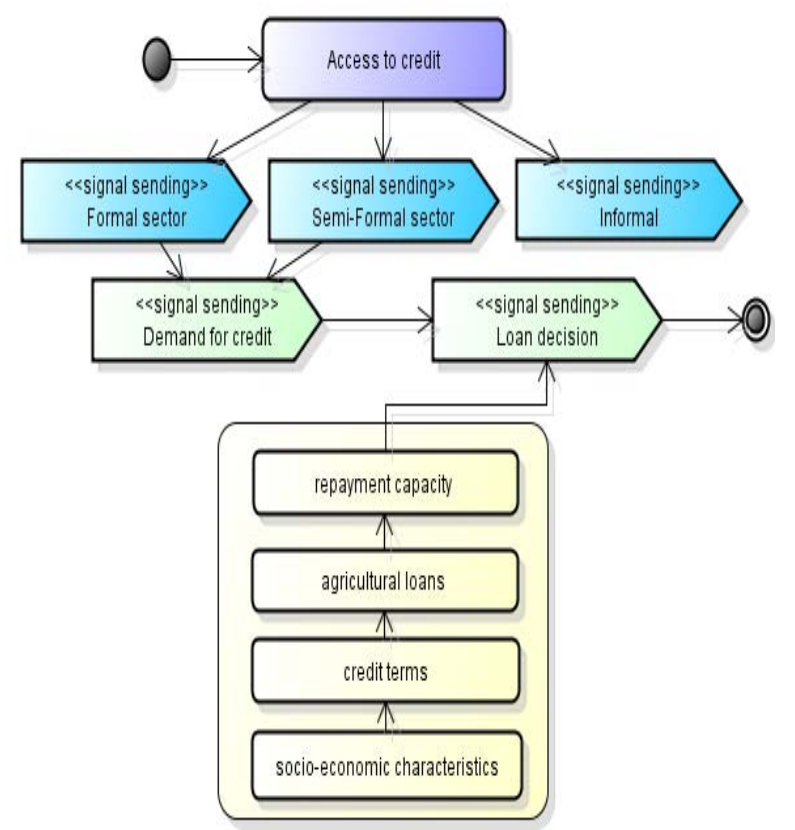

Fig. 1: Determinants of access to credit. Source: Author's summary.
In this sense, credit managers are concerned about the initial stage because it provides useful information to help the decision-making process to improve access to credit by the majority of small-scale producers. In this way, it has to be observed that was financing agricultural credit with appropriate criteria is not a trivial solution, it is necessary to take into account some particularities that go beyond technical issues, which cannot be ignored, such as trust, management of Cultural diversity, education, domestic wealth, land fragmentation and credit amount Hussien Komicha and Bo Öhlmer (2007).

\section{ili. Systematic Review Process}

A systematic review of the literature emerges as a means of evaluating and interpreting all available researches relevant to a particular research question, thematic area, or phenomenon of interest with scientific value Kitchenham (2007). The systematic review intends to present a fair evaluation of a research topic, using a reliable, rigorous, and auditable methodology Kitchenham (2007). Thus, the objective of this review is to identify existing solutions to support credit and portfolio managers in decision-making based on indicators in the financing of agricultural credit to rural families. The evaluation of the quality of the studies have classified according to the proposal in Dyba and Dingsoyr (2008).

\section{a) Definition of research issues}

The formulation of the questions and strings of research presented is adapted from Santos (2007) includes the elements defined below:

- Population: Which set will be the subject of the review? Works that discuss the combination of techniques the financing of agricultural credit; recommendations of the evaluation using indicators;

- Intervention: What have be evaluated in this set of elements of the population? These are the technical approaches and methods for assessing the financing of agricultural credit;

- Comparison: Elements that will serve as a basis for comparison, considering the similarities of objectives, presented in section 5;

- Outcomes: Output information expected with the search. Comparative study of the approaches and analysis of the methods used in the financing of agricultural credit aimed at investigating the limitations and potentiality of existing evaluation approaches.

Seeking to direct efforts during the execution and understanding of the State of research on issues related to metrics and indicators to support the financing of agricultural credit in various geographic locations, the following Research issues led to this study: 
Q1: Based on the evidence found, what information is used to aid the financing of agricultural credit to rural families?

Q2: What empirical research methods where used?

Q3: What types of research contributions have been found?

\section{b) Description of Search Strategies}

Bibliographic research consisted of two phases. In stage 1, electronic databases have to be researched with the keywords that guide the research to answer the questions. The search strings were generated from the combination of the key terms and synonyms using OR and AND, possible peculiarities of the digital libraries and adaptations to have to be recorded. Therefore, the research should be done in the English language, combining the synonyms defined in table I. Thus, the studies were obtained from the following sources:

- IEEE Xplore (http://ieeexplore.ieee.org/)

- Elsevier Science Direct (www.sciencedirect.com)

- Google Scholar (http://scholar.google.com)

- Citeseerx (http://citeseer.ist.psu.edu/index)

- Academia (https://www.academia.edu/)

- Semantic Scholar (https://www.semanticscholar. org/)

In the second stage, manual conduction has to be conducted in the rural observer, symposiums and conferences (International Conference on African Development) to find articles relevant to the research published between 2003 and 2019.

The events have maintained a good number of articles submitted, which has significantly accentuated the presence of foreign researchers. In these specific cases, the search for the articles will have to be conducted in Portuguese and English to cover the largest number of cases relevant to answer the research questions. The selected document types based on expert queries represented in table II.

Table I: Keywords used the Study

\begin{tabular}{|c|c|}
\hline \multicolumn{2}{|r|}{ String } \\
\hline Population & $\begin{array}{l}\text { "Access to rural credit of } \\
\text { households/farmers ," "access to } \\
\text { rural loans of households/farmers ," } \\
\text { "factors affecting access to rural } \\
\text { credit ," "Determinants of access to } \\
\text { rural credit ," "Rural credit markets," } \\
\text { "Credit Restrictions ", "Credit share } \\
\text {," "Credit terms ," "Credit refund ," } \\
\text { "Credit refund standards," "Loan } \\
\text { Repayment performance," "socio- } \\
\text { economic characteristics of } \\
\text { households/farmers " }\end{array}$ \\
\hline Intervention & "financing " or "auxiliary in financing " \\
\hline Outcome & "metric " OR "indicator " \\
\hline
\end{tabular}

Table II: Rural Observer, Symposiums and Conferences

\begin{tabular}{|c|l|c|}
\hline Type & \multicolumn{1}{|c|}{ Source } & Acronym \\
\hline Rural Observer & $\begin{array}{l}\text { Rural Environment } \\
\text { Observatory }\end{array}$ & OMR \\
\hline Symposiums & $\begin{array}{l}\text { The International } \\
\text { Symposium on Agriculture }\end{array}$ & AGROSYM \\
\hline Conferences & $\begin{array}{l}\text { International Conference on } \\
\text { African Development }\end{array}$ & TICAD \\
\hline
\end{tabular}

c) Study selection criterion

The initial search for articles returns a lot of studies that are not relevant Kitchenham (2007). Thus, inclusion criteria [I] and exclusion [E] should be based on the research related to the topic addressed. Therefore, irrelevant studies are discarded at the beginning. The inclusion of the document is determined by relevance about research issues by the analysis of the title, abstract, Words - Key, introduction and conclusion. Articles classified as [I] are candidates to become a primary study and articles classified as [E] indicate irrelevant and discarded articles based on the title analysis, summary unrelated to metrics and indicators for financing Agricultural credit. According to the classification below:

[11]. The published papers must relate directly to metrics and indicators to help the financing of agricultural credit to rural families.

[12]. Articles consisting of opinions, recommendations of the evaluation using metrics and indicators for support and understanding the financing of agricultural credit.

[E1]. Repeated studies. If it is available in different search sources, the first is considered.

\section{Study Results}

\section{a) General vision of Studies}

The review was conducted in the period from January to August 2019, according to the plan presented in section 3 .

Figure 2 illustrates the course performed for the studies found in the set with the search string in the sources used and manual search.

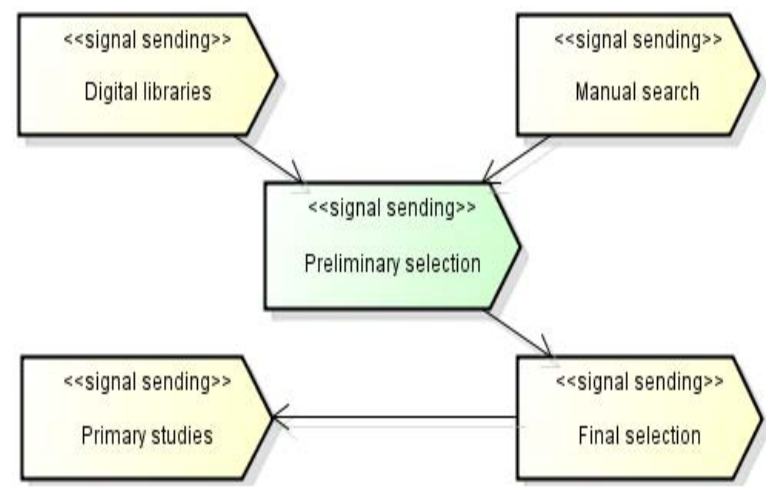

Fig. 2: Search filter and choice of primary studies

The search procedure produced 64 initial studies. Of these 64 were not repeated, after the initial 
search (preliminary selection), 42 articles were preselected because they were relevant to identify primary studies by reading the title, summary and conclusion. From analise, a new subset was obtained by the reading criterion in depth through the total reading of the article Remained those who presented consistent information about metrics and indicators for the financing of agricultural credit. In this second stage (final selection) 18 studies were selected for a detailed comparative analysis (Table $\mathrm{X}$ ).

A study on accessibility metrics and loan restrictions in the agricultural sector has increased in recent years, particularly since 2012. The number of publications in 2019 was not discrete since the data were collected in August 2019. Table III shows the frequency of publication of the selected papers from 2003 to 2019.

Table III: Trend of Publications (Per Year)

\begin{tabular}{|c|c|c|}
\hline Year & Percentage (\%) & Frequency \\
\hline 2003 & 5.56 & 1 \\
\hline 2005 & 5.56 & 1 \\
\hline 2007 & 5.56 & 1 \\
\hline 2008 & 5.56 & 1 \\
\hline 2009 & 5.55 & 1 \\
\hline 2010 & 5.55 & 1 \\
\hline 2012 & 16.67 & 3 \\
\hline 2013 & 5.55 & 1 \\
\hline 2015 & 5.55 & 1 \\
\hline 2016 & 5.55 & 1 \\
\hline 2018 & 11.11 & 2 \\
\hline 2019 & 22.23 & 4 \\
\hline
\end{tabular}

Figure 3 Maps the source of the publications, most of the studies are Journal (94.45\%). The distribution is as follows: Rural Observer (0), conferences (5.55\%), and symposiums (0).

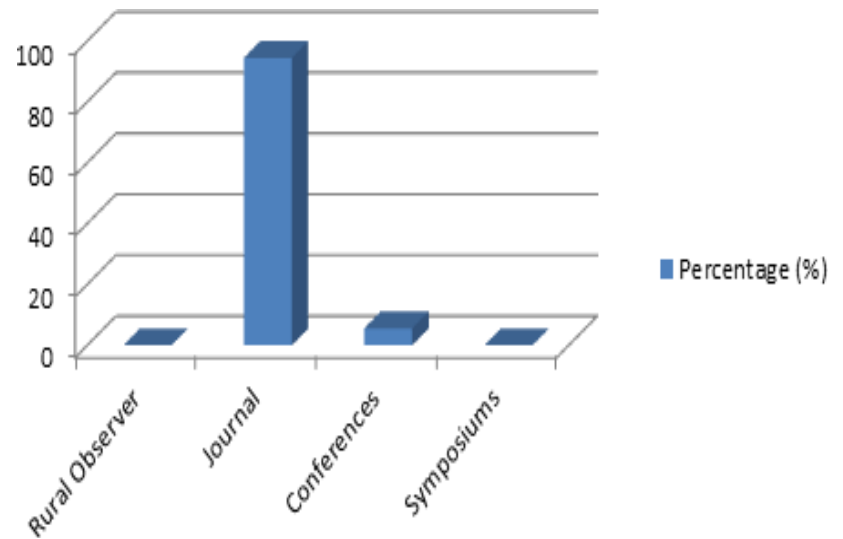

Fig. 3: Publication by Source Type

b) Classification of studies

The process of extracting information has to be based on the focus of studies presented in table IV. Thus, a categorization between objective and subjectivity of the results was established. The articles revealed problems or evaluation of solutions, where
$5.55 \%$ deal with determinants of repayment and performances in microcredit programs that can be divided into three factors: borrower, firm and lender; $11.11 \%$ discuss the determinants of credit terms and repayment performance; the focus of $27.78 \%$ on access to agricultural loans, characteristics of the borrowers rural and socio-economic credit markets; $50 \%$ practices to guide repayment capacity, socio-economic characteristics of rural farmers, factors affecting demand for credit and repayment performance; Highlighted issues $5.56 \%$ on evidence of factors affecting the amortization rate and institutional.

Thus, we followed the classification of each publication according to the configuration of the study presented in table $\mathrm{V}$, almost $61.11 \%$ of the studies are from the market; $27.78 \%$ are academic, and $11.11 \%$ are in the research project scenarios.

Table N: Study Focus

\begin{tabular}{|c|c|c|}
\hline Article result & Percentage (\%) & Frequency \\
\hline Issues & 0 & 0 \\
\hline Mixed & 94.45 & 17 \\
\hline Strategy & 5.55 & 1 \\
\hline
\end{tabular}

Table V: Distribution of Studies

\begin{tabular}{|c|c|c|}
\hline Study Configuration & Percentage (\%) & Frequency \\
\hline Market & 61.11 & 11 \\
\hline Academic & 27.78 & 5 \\
\hline Research Project & 11.11 & 2 \\
\hline
\end{tabular}

c) Based on the evidence found, what information is used to aid the financing of agricultural credit to rural families? Q1

In the primary studies carried out and, also in the current literature, some metrics identified standard repayment credit criteria in table VI and VII, respectively. For example, in the work of Bob Ssekiziyivu et al. (2018) used credit terms and repayment performance of loans, having as the collateral requirement, loan period and interest rate, while experimental study of Matusse (2019) seeks to establish (co) relationships and demonstrates how repayment capacity affects the accessibility of the loan of farmers in Boane district using metrics, to extract an indicator to aid agricultural credit financing to rural family and to support credit managers in decisionmaking.

In another study, Fred Nimoh et al. (2012) discusses the factors influencing the pattern of credit then proceeds with policy recommendations based on the results to help simplify the operations of similar governmental projects. Fred Nimoh et al. (2012) will conclude the probit model explains the probability of delinquency of credit as a result of the independent variables identified. In the approach proposed by Hussien Komicha and Bo Öhlmer (2007), a set of practices to estimate the technical efficiency of agricultural credit restriction of farmers, employing the 
stochastic frontier technique in data from research in Southeastern Ethiopia.

The theoretical study by Ben Soltane Bassem (2008) investigated and described the main vulnerable factors affecting the performance of repayment of group loans in the states of Tunisia. Criteria identified according to the classification proposed by Abiodun et al. (2019) presented in table VII.

Thus, the data presented in table $\mathrm{VI}$ and VII show that there is only one article related to indicators derived from the correlation between the metrics to support credit managers and portfolio in decisionmaking, by Matusse (2019).

\section{Table VI: Identified Metrics}

\begin{tabular}{|c|c|}
\hline Metrics & Autores \\
\hline $\begin{array}{l}\text { Factors influencing credit accessibility, } \\
\text { restriction on agricultural credit }\end{array}$ & $\begin{array}{c}{[1][2]} \\
{[10][15]} \\
{[14][25]} \\
{[19]}\end{array}$ \\
\hline 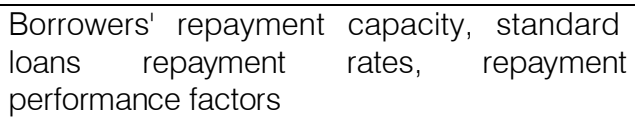 & $\begin{array}{l}{[4][24]} \\
{[26][6]}\end{array}$ \\
\hline $\begin{array}{l}\text { Lending affordability and repayment } \\
\text { capabilities prospect of borrowers, credit } \\
\text { terms and repayment performance of loans }\end{array}$ & [5] [12] \\
\hline $\begin{array}{l}\text { Socio-economic characteristics of borrowers, } \\
\text { characteristics of rural credit markets, credit } \\
\text { standard and loan repayment delinquency }\end{array}$ & $\begin{array}{c}{[13][17]} \\
{[30]}\end{array}$ \\
\hline $\begin{array}{l}\text { Factors affecting the amortization rate, } \\
\text { repayment performance of loans and } \\
\text { institutional factors }\end{array}$ & $\begin{array}{c}\text { [24] [32] } \\
{[3]}\end{array}$ \\
\hline
\end{tabular}

Table VII: Analysis Criterion

\begin{tabular}{|c|c|}
\hline Criteria & Classification \\
\hline $\begin{array}{l}\text { Interest rates, loan period, } \\
\text { warranty requirements, distance } \\
\text { from loan sources, the amount } \\
\text { granted, profitability and portfolio } \\
\text { diversity }\end{array}$ & $\begin{array}{l}\text { Determinants of } \\
\text { access to credit, } \\
\text { and repayment } \\
\text { capacity }\end{array}$ \\
\hline $\begin{array}{l}\text { Age, educational level, gender, } \\
\text { business experience, monthly } \\
\text { income, household; threat } \\
\text { imposed by creditors, regular } \\
\text { monitoring, cost of the transaction; } \\
\text { loan amount, amortization method, } \\
\text { amortization period }\end{array}$ & $\begin{array}{l}\text { Characteristics of } \\
\text { borrowers, firm and } \\
\text { lender }\end{array}$ \\
\hline $\begin{array}{l}\text { Poor rains, burnt, provision of the } \\
\text { late entry, pest infestation; legal } \\
\text { structure, ownership/control/ } \\
\text { financing, leadership, human } \\
\text { resources, management, auditing }\end{array}$ & $\begin{array}{l}\text { Delinquency } \\
\text { characteristics of } \\
\text { repayment and } \\
\text { institutional factors }\end{array}$ \\
\hline
\end{tabular}

d) What empirical research methods were used? Q2

The articles is classified according to the method used by Tonella (2007), which consists of five research methods: 1) Literature review (means of evaluating and interpreting existing researches); 2) Experimental (studies that apply to measure any specific effect and controls); 3) descriptive research;
4) Exploratory research (record of lessons learned); and 5) Case study (Investigation of real-world situations). Although the exploratory research and survey method is not part of the method used by Tonella (2007), it was included in table VIII by the method used in the research, where $5.55 \%$ were experimental studies; (27.78\%) descriptive research; (16.67) comprise the theoretical study; (22.23\%) used the case study method; (5.55\%) literature review; (5.55\%) exploratory study, and (16.67\%) reports from the survey.

\section{Table VIII: Search Method used}

\begin{tabular}{|l|c|c|}
\hline \multicolumn{1}{|c|}{ Search method } & Percentage (\%) & Frequency \\
\hline Literature Review & 5.55 & 1 \\
\hline Descriptive research & 27.78 & 5 \\
\hline Case study & 22.23 & 4 \\
\hline Experimental study & 5.55 & 1 \\
\hline Theoretical study & 16.67 & 3 \\
\hline Exploratory study & 5.55 & 1 \\
\hline Survey & 16.67 & 3 \\
\hline
\end{tabular}

e) What types of research contributions have been found? Q3

According to the classification developed for research needs, table IX illustrates the primary research of studies. Thus, the distribution is as follows $11.11 \%$ of the articles deal with the proposed solution; evaluation survey (66.67\%); analysis research articles (16.67\%); (5.55\%) research validation article.

\section{Table IX: Contribution Types of Research}

\begin{tabular}{|c|c|c|}
\hline Search Type & Percentage (\%) & Frequency \\
\hline Solution proposal & 11.11 & 2 \\
\hline Validation Search & 5.55 & 1 \\
\hline Evaluation Survey & 66.67 & 12 \\
\hline Analysis Research & 16.67 & 3 \\
\hline
\end{tabular}

V. Analysis of Existing Solutions to Support the FinANCing of

\section{Agricultural Credit to Rural Family}

During data extraction, it was not possible to identify the correlation of credit terms and repayment capacity, since the level of flexibility of the credit terms was directly associated with the repayment level of the Ndiege loan (2016), but We used the criteria of guarantee requirement, loan period and the interest rate that composes a particular project in the credit application process Eze and Ibekwe, (2007). Based on the assumption that there is a relationship between the credit term that makes up the process and the reimbursement capacity to rural families, factors affecting the access of small farmers to formal credit has been included in the study and shows that improving access to extension services and the possession of secure land in order to increase production and productivity, Lighton Dube et al. (2015). However, work of Allan Mitei et. al. (2016) identifies and 
analyzes the types of classification that refer to social factors that affect the repayment of loans by borrowers.
Table $\mathrm{X}$ presents the main comparative analysis of the models identified.

Table X: Models Proposed and Identified During the Systematic Review

\begin{tabular}{|c|c|c|c|c|c|}
\hline Search model & Related articles & Search method & Techniques & Features & $\begin{array}{l}\text { Search } \\
\text { Type }\end{array}$ \\
\hline $\begin{array}{l}\text { Study to identify determinants } \\
\text { of repayment and } \\
\text { performances in microcredit } \\
\text { programs that have to be } \\
\text { divided into four factors: } \\
\text { borrower, firm and lender }\end{array}$ & $\begin{array}{l}\text { Nawai e Shariff, } \\
(2010)\end{array}$ & Literature Review & $\begin{array}{l}\text { Evidence } \\
\text { Gathering }\end{array}$ & $\begin{array}{l}\text { Characteristics of the } \\
\text { borrower, } \\
\text { characteristics of the } \\
\text { firm, characteristics } \\
\text { of the lender }\end{array}$ & $\begin{array}{l}\text { Evaluation } \\
\text { Research }\end{array}$ \\
\hline $\begin{array}{l}\text { The study sought to establish } \\
\text { the social factors that affect } \\
\text { the repayment of loans by } \\
\text { borrowers, to determine } \\
\text { economic factors that affect } \\
\text { the repayment of the loan by } \\
\text { borrowers. }\end{array}$ & $\begin{array}{l}\text { Allan Mitei et al. } \\
\qquad(2016)\end{array}$ & $\begin{array}{l}\text { Descriptive } \\
\text { research }\end{array}$ & $\begin{array}{l}\text { Descriptive } \\
\text { statistics and } \\
\text { multiple } \\
\text { regressions }\end{array}$ & $\begin{array}{l}\text { Loan standard, loan } \\
\text { repayment, loan } \\
\text { factor terms }\end{array}$ & $\begin{array}{l}\text { Solution } \\
\text { proposal }\end{array}$ \\
\hline $\begin{array}{l}\text { The study describes the } \\
\text { socioeconomic characteristics } \\
\text { of the interviewees analyzed } \\
\text { the factors that determine the } \\
\text { access of farmers to formal } \\
\text { and informal agricultural loans } \\
\text { and identified } \\
\text { their restrictions }\end{array}$ & $\begin{array}{l}\text { Abiodun, et al. } \\
\text { (2009) }\end{array}$ & $\begin{array}{l}\text { Descriptive } \\
\text { research }\end{array}$ & $\begin{array}{c}\text { Descriptive } \\
\text { statistics and } \\
\text { binomial test } \\
\text { model }\end{array}$ & $\begin{array}{l}\text { Access to formal } \\
\text { and informal } \\
\text { agricultural loans, } \\
\text { restrictions on } \\
\text { access to } \\
\text { agricultural loans }\end{array}$ & $\begin{array}{l}\text { Analysis } \\
\text { Research }\end{array}$ \\
\hline $\begin{array}{l}\text { The work investigated the } \\
\text { lending rate and repayment } \\
\text { capacity of the borrowers of } \\
\text { the micro-finance banks } \\
\text { (MFBs) at Oyo State in the } \\
\text { southwest, Nigeria }\end{array}$ & $\begin{array}{l}\text { Adu, et al. } \\
\text { (2019) }\end{array}$ & Case study & $\begin{array}{l}\text { Descriptive } \\
\text { statistics and } \\
\text { Cox } \\
\text { regression }\end{array}$ & $\begin{array}{l}\text { Determinants of } \\
\text { repayment capacity } \\
\text { of borrowers }\end{array}$ & $\begin{array}{l}\text { Analysis } \\
\text { Research }\end{array}$ \\
\hline $\begin{array}{l}\text { The research investigated the } \\
\text { repayment of the loan in the } \\
\text { southeastern states of Nigeria, } \\
\text { using multiples sampling } \\
\text { techniques in three segments } \\
\text { (formal, semi formal and } \\
\text { informal) }\end{array}$ & $\begin{array}{l}\text { Onyeagocha, et } \\
\text { al. (2012) }\end{array}$ & Case study & $\begin{array}{l}\text { Ordinary } \\
\text { multiple } \\
\text { regression } \\
(\text { OLS })\end{array}$ & $\begin{array}{l}\text { Determinants of loan } \\
\text { repayment }\end{array}$ & $\begin{array}{l}\text { Analysis } \\
\text { Research }\end{array}$ \\
\hline $\begin{array}{l}\text { The research seeks to } \\
\text { establish (co) relationships } \\
\text { and demonstrate how } \\
\text { repayment capacity affects the } \\
\text { accessibility of the loan of } \\
\text { farmers in Boane district using } \\
\text { metrics, to extract an indicator }\end{array}$ & $\begin{array}{c}\text { Euclides } \\
\text { Alfredo } \\
\text { Matusse (2019) }\end{array}$ & $\begin{array}{l}\text { Goal Question } \\
\text { Metric }\end{array}$ & $\begin{array}{l}\text { Spearman's } \\
\text { non- } \\
\text { parametric } \\
\text { correlation }(p)\end{array}$ & $\begin{array}{l}\text { Determinants of } \\
\text { lending accessibility, } \\
\text { determinants of loan } \\
\text { repayment }\end{array}$ & $\begin{array}{l}\text { Validation } \\
\text { Search }\end{array}$ \\
\hline $\begin{array}{l}\text { The research examined the } \\
\text { determinants of access and } \\
\text { demand for formal credit by } \\
\text { small cassava farmers in } \\
\text { Okene, Okehi, and a Davi } \\
\text { areas of the local government } \\
\text { of the state of Kogi. }\end{array}$ & $\begin{array}{c}\text { Adebayo C.O. } \\
\text { (2018) }\end{array}$ & $\begin{array}{c}\text { Primary data } \\
\text { through a } \\
\text { questionnaire and } \\
\text { descriptive } \\
\text { statistics }\end{array}$ & Probit model & $\begin{array}{l}\text { Factors affecting } \\
\text { credit demand, } \\
\text { restrictions on formal } \\
\text { credit demand, } \\
\text { determinants of } \\
\text { credit access among } \\
\text { small-scale manioc } \\
\text { farmers }\end{array}$ & $\begin{array}{l}\text { Evaluation } \\
\text { Research }\end{array}$ \\
\hline
\end{tabular}




\begin{tabular}{|c|c|c|c|c|c|}
\hline $\begin{array}{l}\text { The research study was to } \\
\text { establish the relationship } \\
\text { between } \\
\text { characteristics of borrowers, } \\
\text { the credit terms and the } \\
\text { amount of repayment of loans } \\
\text { from MFI customers in the } \\
\text { district of Luwero Kampala }\end{array}$ & $\begin{array}{c}\text { Bob Ssekiziyivu } \\
\text { et al. } \\
(2018)\end{array}$ & $\begin{array}{c}\text { Primary data } \\
\text { through a } \\
\text { questionnaire and } \\
\text { descriptive } \\
\text { statistics }\end{array}$ & $\begin{array}{l}\text { Pearson } \\
\text { Correlation } \\
\text { analysis and } \\
\text { regression } \\
\text { analysis }\end{array}$ & $\begin{array}{l}\text { Determinants of } \\
\text { credit terms, factors } \\
\text { and characteristics } \\
\text { of borrowers, } \\
\text { repayment } \\
\text { performance of } \\
\text { loans }\end{array}$ & $\begin{array}{l}\text { Evaluation } \\
\text { Research }\end{array}$ \\
\hline $\begin{array}{l}\text { The research seeks to } \\
\text { discover the factors } \\
\text { influencing the standard of } \\
\text { credit, then make policy } \\
\text { recommendations based on } \\
\text { the results to help simplify the } \\
\text { operations of similar } \\
\text { governmental projects. }\end{array}$ & $\begin{array}{c}\text { Fred Nimoh1 et } \\
\text { al. (2012) }\end{array}$ & $\begin{array}{l}\text { Primary data were } \\
\text { collected by the } \\
\text { use of structured } \\
\text { questionnaires and } \\
\text { interviews. }\end{array}$ & Probit model & $\begin{array}{l}\text { Credit Standard } \\
\text { determinants, socio- } \\
\text { economic characteri- } \\
\text { stics of borrowers, } \\
\text { defaults (reasons) of } \\
\text { repayment } \\
\text { delinquency }\end{array}$ & $\begin{array}{l}\text { Evaluation } \\
\text { Research }\end{array}$ \\
\hline $\begin{array}{l}\text { The research focuses on rural } \\
\text { credit markets, the } \\
\text { determinants of farmers' } \\
\text { access to markets, the socio- } \\
\text { economic impacts of access } \\
\text { to credit }\end{array}$ & $\begin{array}{c}\text { Ta Nhat Linh et } \\
\text { al. (2019) }\end{array}$ & $\begin{array}{l}\text { Detailed literature } \\
\text { review with } \\
\text { secondary data } \\
\text { collection and } \\
\text { interviews }\end{array}$ & Probit model & $\begin{array}{l}\text { Determinants of } \\
\text { access to rural } \\
\text { credit, socio- } \\
\text { Economic charact- } \\
\text { eristics of borrowers, } \\
\text { rural credit markets }\end{array}$ & $\begin{array}{l}\text { Evaluation } \\
\text { Research }\end{array}$ \\
\hline $\begin{array}{l}\text { The research sought to identify } \\
\text { factors that limit or increase } \\
\text { the formal access to credit for } \\
\text { small farmers in the Asebu } \\
\text { Kwamankese Abura District in } \\
\text { central Ghana. }\end{array}$ & $\begin{array}{l}\text { Dzadze P. et al. } \\
\text { (2019) }\end{array}$ & $\begin{array}{c}\text { Descriptive } \\
\text { statistics and a } \\
\text { logistic binary } \\
\text { model }\end{array}$ & $\begin{array}{l}\text { Logistic } \\
\text { regression } \\
\text { model/logistic } \\
\text { regression } \\
\text { model }\end{array}$ & $\begin{array}{l}\text { Determinants of } \\
\text { credit Access }\end{array}$ & $\begin{array}{l}\text { Evaluation } \\
\text { Research }\end{array}$ \\
\hline $\begin{array}{l}\text { The research sought to } \\
\text { determine factors influenced } \\
\text { the standard rates of } \\
\text { repayment of loans among } \\
\text { poultry farmers in ljebu Ode } \\
\text { Local Government Area of } \\
\text { Ogun State Nigeria }\end{array}$ & Oni O.A, (2005) & $\begin{array}{c}\text { Structured } \\
\text { questionnaires, } \\
\text { descriptive } \\
\text { statistics }\end{array}$ & Probit model & $\begin{array}{l}\text { Determinants of } \\
\text { factors influenced } \\
\text { standard loans } \\
\text { repayment rates, } \\
\text { socio- economic } \\
\text { characteristics of } \\
\text { borrowers }\end{array}$ & $\begin{array}{l}\text { Evaluation } \\
\text { Research }\end{array}$ \\
\hline $\begin{array}{l}\text { The research study was to } \\
\text { determine the factors the } \\
\text { accessibility of formal credit by } \\
\text { the small farmers, artisanal } \\
\text { fishermen in the attendance to } \\
\text { the sector of microenterprises. }\end{array}$ & $\begin{array}{l}\text { Khalid } \\
\text { Mohamed } \\
\text { (2003) }\end{array}$ & $\begin{array}{c}\text { Structured } \\
\text { questionnaires, } \\
\text { descriptive } \\
\text { statistics, cross } \\
\text { tabulations by } \\
\text { means of } \\
\text { computer software } \\
\text { STATA } 7\end{array}$ & $\begin{array}{c}\text { Regressions } \\
\text { and T-Test }\end{array}$ & $\begin{array}{l}\text { Factors influencing } \\
\text { the accessibility of } \\
\text { credit, socio- } \\
\text { economic } \\
\text { characteristics of } \\
\text { borrowers }\end{array}$ & $\begin{array}{l}\text { Evaluation } \\
\text { Research }\end{array}$ \\
\hline $\begin{array}{l}\text { The research examined the } \\
\text { determinants of credit access } \\
\text { by rural farmers in the state of } \\
\text { Oyo Nigeria }\end{array}$ & $\begin{array}{c}\text { Ololade R.A. \& } \\
\text { Olagunju F.I. } \\
\text { (2013) }\end{array}$ & $\begin{array}{l}\text { Structured } \\
\text { questionnaires, } \\
\text { descriptive } \\
\text { statistics and } \\
\text { multistage } \\
\text { sampling } \\
\text { procedure }\end{array}$ & $\begin{array}{l}\text { Logit/Binomia } \\
\text { I Logistic } \\
\text { Regression } \\
\text { model }\end{array}$ & $\begin{array}{l}\text { Socio-economic } \\
\text { characteristics of } \\
\text { rural } \\
\text { farmers }\end{array}$ & $\begin{array}{l}\text { Evaluation } \\
\text { Research }\end{array}$ \\
\hline $\begin{array}{l}\text { The research investigated the } \\
\text { factors affecting small farmers' } \\
\text { access to formal credit and } \\
\text { shows that improving } \\
\text { extension services and the } \\
\text { possession of secure land in } \\
\text { order to increase production } \\
\text { and productivity in Zimbabwe. }\end{array}$ & $\begin{array}{l}\text { Lighton Dube et } \\
\text { al. (2015) }\end{array}$ & $\begin{array}{l}\text { Questionnaires, } \\
\text { descriptive } \\
\text { statistics and } \\
\text { inferential } \\
\text { statistics }\end{array}$ & $\begin{array}{l}\text { Logit } \\
\text { regression } \\
\text { model/Logisti } \\
\text { c binary } \\
\text { regression }\end{array}$ & $\begin{array}{l}\text { Socio-economic } \\
\text { characteristics of } \\
\text { rural farmers, factors } \\
\text { affecting access to } \\
\text { credit, restrictions } \\
\text { identified rural } \\
\text { farmers }\end{array}$ & $\begin{array}{l}\text { Evaluation } \\
\text { Research }\end{array}$ \\
\hline
\end{tabular}




\begin{tabular}{|c|c|c|c|c|c|}
\hline $\begin{array}{l}\text { A set of practices to estimate } \\
\text { the technical efficiency of } \\
\text { agricultural credit restriction of } \\
\text { farmers, employing the } \\
\text { stochastic frontier technique in } \\
\text { data from research in } \\
\text { Southeastern Ethiopia. }\end{array}$ & $\begin{array}{l}\text { Hussien Hamda } \\
\text { Komicha \& Bo } \\
\text { Öhlmer (2007) }\end{array}$ & $\begin{array}{l}\text { Descriptive } \\
\text { statistics and } \\
\text { inferential } \\
\text { statistics }\end{array}$ & $\begin{array}{l}\text { Stochastic } \\
\text { frontier }\end{array}$ & $\begin{array}{l}\text { Characteristics } \\
\text { restriction to } \\
\text { agricultural credit }\end{array}$ & $\begin{array}{l}\text { Evaluation } \\
\text { Research }\end{array}$ \\
\hline $\begin{array}{l}\text { The research investigated and } \\
\text { described the main vulnerable } \\
\text { factors affecting the } \\
\text { repayment performance of } \\
\text { group loans. }\end{array}$ & $\begin{array}{l}\text { Ben Soltane } \\
\text { Bassem } \\
(2008)\end{array}$ & $\begin{array}{c}\text { Descriptive } \\
\text { questionnaires and } \\
\text { statistics }\end{array}$ & Logit model & $\begin{array}{l}\text { Repayment } \\
\text { Performance factors }\end{array}$ & $\begin{array}{l}\text { Solution } \\
\text { proposal }\end{array}$ \\
\hline $\begin{array}{l}\text { The study sought to } \\
\text { investigate the repayment of } \\
\text { loans and the financial } \\
\text { performance of SACCO's in } \\
\text { the municipality of Embu, } \\
\text { Keny. }\end{array}$ & $\begin{array}{l}\text { Katula R. \& } \\
\text { Kiriinya } \\
\text { S. (2018) }\end{array}$ & $\begin{array}{l}\text { Questionnaires } \\
\text { through the Drop } \\
\text { and Pick method }\end{array}$ & $\begin{array}{l}\text { Cronbach's } \\
\text { Alpha } \\
\text { method, } \\
\text { Multiple } \\
\text { regression }\end{array}$ & $\begin{array}{l}\text { Loan appraisal, loan } \\
\text { interest rates, loan } \\
\text { follow-up procedures } \\
\text { and customer } \\
\text { characteristics }\end{array}$ & $\begin{array}{l}\text { Evaluation } \\
\text { Research }\end{array}$ \\
\hline
\end{tabular}

a) Evaluation of the quality of the studies

The analysis of the studies followed criteria established for the Evaluation of experimental studies present in Dyba (2008). The screening criteria were related to the quality of the reasoning communication of a study according to the caption below:

$\checkmark$ Caption: This issue is within this area of responsibility

Issues:

1. Has the study reported empirical research or was it just considered as lessons learned, the report based an expert opinion?

2. Have the goals been reported?

3. Was there an adequate description of the context in which the research was conducted?

4. Was the research project suitable for attacking the research objectives?

5. Was there an adequate description of the sample used and the methods to identify and recruit the samples?

6. No control group was used to compare treatments?

7. Adequate data collection methods were used and described?

8. There was an adequate description used to analyze the appropriate methods to ensure that data analysis??

9. The relationship between the researcher and the research participants is appropriate??

10. Has the study provided credible results and justified conclusions??

11. Have they provided the value for research or practice?

From table XI, it is observed that the evaluation of the study consists in verifying the adequacy of the framing of the articles in the area of responsibilities according to the questions pre-established by the criterion adopted by Dyba (2008).
Table XI: Evaluation of the Quality of Studies

\begin{tabular}{|c|c|c|c|c|c|c|c|c|c|c|c|}
\hline \multirow{2}{*}{ Articles } & \multicolumn{11}{|c|}{ Criteria } \\
\hline & 1 & 2 & 3 & 4 & 5 & 6 & 7 & 8 & 9 & 10 & 11 \\
\hline [19] & घ & a & घ & a & घ & घ & घ & घ & a & 口 & a \\
\hline [2] & - & 口 & a & 口 & 口 & - & a & - & a & 口 & 口 \\
\hline [5] & 口 & 口 & a & - & 口 & घ & $\square$ & - & $\square$ & I & ! \\
\hline [13] & 口 & 口 & - & 口 & 口 & - & ㅁ & - & ㅁ & 口. & 口 \\
\hline [30] & घ & - & a & a & " & & - & & a & " & घ \\
\hline [10] & - & - & - & - & - & - & - & - & & - & 口 \\
\hline [26] & - & 口 & - & a & 口 & - & घ & - & a & " & a \\
\hline [15] & घ & 口 & घ & . & 口 & 口 & 口 & - & 口 & घ & 口 \\
\hline [25] & - & - & - & - & - & - & - & - & - & - & I \\
\hline [3] & घ & घ & घ & 口 & 口 & . & 口 & - & 口 & घ & 口 \\
\hline [1] & - & - & - & . & - & - & 口 & - & - & $\square$ & 口 \\
\hline [4] & - & - & - & - & 口 & - & - & - & - & - & 口 \\
\hline [24] & 口 & 口 & 口 & 口 & 口 & 口 & ㅁ & - & 口 & घ & 口 \\
\hline [12] & - & $\square$ & $\pi$ & a & $\square$ & घ & $\square$ & a & & 口 & I \\
\hline [17] & घ & $\square$ & a & घ & घ & घ & घ & घ & घ & 口 & a \\
\hline [14] & 口 & $\square$ & घ & $\square$ & 口 & 口 & $\square$ & घ & $\square$ & & 口 \\
\hline [6] & घ & 口 & घ & 口 & 口 & & 口 & घ & a & 口 & 口 \\
\hline [32] & घ & $\square$ & घ & घ & & घ & 口 & a & & & a \\
\hline
\end{tabular}

\section{Conclusion}

In this paper, we analyze the results of the systematic review of 18 studies in metrics and indicators to aid in the financing of agricultural loans to rural families. The research presents the relation of the characteristics of research studies published per year, type of research used, characteristics and techniques approached. This research is important because of it highlights gaps and opportunities in evidence on the use of indicators to support the financing of agricultural credit. Based on the data collected, it is possible to identify the following conclusions:

Conclusion \# 1: Most studies are related to the accessibility of agricultural credit in rural families and contexts based on evaluation research.

Most studies are related to issues of determinants affecting access to formal credit and 
determining repayment from the perspective of borrowers, which means that researchers tend to discover the problems by the theoretical and descriptive study rather than proposing an experimental study.

Conclusion \# 2: There is a shortage of research focusing on metrics in the financing of agricultural credit in microcredit institutions.

There are two plausible reasons for the lack of this research focus: 1) Although access to credit is an significant factor in the adoption of agricultural technologies and increased agricultural incomes among rural farmers, are generally not sufficiently mature to make use of measurements or 2) researchers are not yet widely aware of the need for exploratory studies that identifies a mechanism to propose an agricultural credit financing strategy based on indicators through the analysis of a set of metrics, to predict and evaluate how technical and non-technical, human behavior and communication aspects affect both microfinance institutions and borrowers in the repayment of the loan.

Conclusion \# 3: There is a need for further studies focusing on quality metrics and indicators to infer a total index in the financing of agricultural loans to rural families.

The results of the review shown in table $X$ indicate that most of the proposals so far are, in large part, related the issues accessibility of agricultural credit to farmers and significant factors of constraints separately based on Analysis of association variables. The results of the articles do not suggest studies of the relationship between metrics and indicators analyzing the four determinants such as access to formal agricultural loans, repayment capacity, credit terms and socio-economic characteristics of borrowers.

In this context, it is believed that the evaluation of metrics related to indicators becomes necessary to ensure that the quality in the financing of agricultural credit offering a prospect to the credit manager and portfolio to measure and monitor their expertise in services of microcredit.

\section{FUTURE WORKS}

The result of the work identified a series of difficulties to address agricultural credit financing based on metrics and indicators to the rural family. The causes of this difficulty are related to processes and terms of access to agricultural credit unstable to make use of measurements. Its complexity increases with the effect of late arrival of the credit package resulting from the reasons such as fires, pest infestation and weak rainy season. The terms and conditions offered to borrowers should be revised, making it more flexible to suit farmers As future work, we intend to elaborate an agribusiness simulator to assist in the financing of agricultural credit based on the correlation of access metrics to formal and informal agricultural loans, credit terms and repayment capacity of borrowers.

\section{AcknOWLedgements}

The author appreciates the financial support of Nhacutse microcredit under process 190504/2019-6.

\section{References Références Referencias}

1. Abiodun S. O., Kuye O. O., Edet, E. U. Determinants of Access to Formal and Informal Agricultural Loan amoung Farmers in Obubra Local Government Area, Cross River State, Nigeria. International Journal in Management and Social Science, Volume 07 Issue 03, March 2019 ISSN: 2321-1784 Impact Factor: 6.178, pages 1-10, 2009.

2. Adebayo C. O. Demand for Formal Credit among Small Scale Cassava Farmers in Kogi State, Nigeria: A Double Hurdle Analysis. Agro- Science Journal of Tropical Agriculture, Food, Environment and Extension. Vol 17 No 2, pp.45-50, May 2018.

3. Allan Mitei, Mary Bosire, Robert Kibet Kirui. Determinants of Loan Default by Savings and Credit Co-Operative Societies' Members in Baringo County, Kenya. iiste European Journal of Business and Management, Vol.8, No.30, 2016.

4. Adu, Cecilia Adurayemi., Owualah, Ikechukwu Sunday., Babajide, Ayopo Abiola. Microfinance Banks' Lending Rate and Repayment Capability of Borrowers in Some Selected Microfinance Banks in Oyo State, Nigeria. Strategic Journal of Business and Social Science. Volume 3. Issue 2 March, 2019.

5. Bob Ssekiziyivu, Juma Bananuka, Isaac Nkote Nabeta and Zainabu Tumwebaze. Borrowers' characteristics, credit terms and loan repayment performance among clients of microfinance institutions (MFIs): Evidence from rural Uganda. Journal of Economics and International Finance JEIF, Vol. 10(1), pp. 1-10, 2018.

6. Ben Soltane Bassem. Determinants of Successful Group Loan Repayment: An Application to Tunisia, V 10, No.2, 2008.

7. CGAP. Donor Brief No.15; CGAP: Washington, DC, USA, 2003.

8. Dyba T. and Dingsoyr T., Empirical studies of agile software development: A systematic review. information and software technology. In:. [S.I.]: Science Direct: Elsevier, 2008.

9. Derban, W. K., Binner, J. M., \& Mullineux, A. (2005). Loan repayment performance in community development finance institutions in the UK. Small Business Economics, 25, 319-332, 2005.

10. Dzadze P., Osei Mensah J., Aidoo R. and Nurah G. $K$. Factors determining access to formal credit in Ghana: A case study of smallholder farmers in the Abura- Asebu Kwamankese district of central region of Ghana. Journal of Development and Agricultural 
Economics. Vol. 4(14), pp. 416-423, December 2012

11. Eze C., Ibekwe U. Determinants of loan repayment under indigenous financial system in Southeast, Nigeria. Medwell Journal, 2(2), 116-120, 2007.

12. Euclides Alfredo Matusse. Experimental Validation of Factors Related to Agricultural Credit Based on Metrics from the Perspective of Borrowers. IOSR Journal of Agriculture and Veterinary Science. Vol 12, Issue 9 Ser. II, PP 50-58, September 2019.

13. Fred Nimoh, Enoch Kwame Tham-Agyekum2, Samuel Ayisu. Factors Influencing Credit Default: A Case Study of Maize Farmers in the Asante Akim North District of Ashanti Region. International Journal of Agriculture and Forestry, Vol. 2(2), pp. 24-28, 2012.

14. Hussien Hamda Komicha \& Bo ÖhImer. Influence of Credit Constraint on Technical Efficiency of Farm Households in Southeastern Ethiopia.International Conference on African Development, 2017.

15. Khalid Mohamed. Access to Formal and QuasiFormal Credit by Smallholder Farmers and Artisanal Fishermen: A Case of Zanzibar. Research on Poverty Alleviation.2003.

16. Yara Nova, Yasser Arafat Dadá e Cerina Mussá. Agricultura em Números Analise do Orçamento do Estado, Investimento, Credito e Balança Comercial. Observador Rural No 74. Observatório do Meio Rural. Maio, Maputo. 2019.

17. Le Thi Minh, C. An Analysis of Access to Credit by Animal Producing Households in Hai Duong Province, Vietnam; Université de Liège Gembloux Agro-Bio Tech: Gembloux, Belgique, 2014.

18. Lighton Dube, Tatenda Mariga and May Mrema. Determinants of Access to Formal Creditby Smallholder Tobacco Farmers in Makoni District, Zimbabwe. Greener Journal of Agricultural Sciences. Vol. 5 (1), pp. 034- 042, 2015.

19. Mohd Noor Mohd Shariff. Determinants of Repayment Performance in Microcredit Programs: A Review of Literature. International Journal of Business and Social Science. Vol. 1 No. 2; November 2010.

20. Mosca, J., Dadá, Y. A. Investimento no Sector Agrário. Observador Rural No 14. Observatório do Meio Rural. Fevereiro, Maputo. 2014.

21. Nawai N., Shariff M.N.M. Determinants of Repayment Performance in Microcredit Programs: A Review of Literature, International Journal of Business and Social Science Vol. 1 No. 2; November 2010, pp 1-10.

22. Njoku, Maria-Stella E. Analysis of Factors Affecting Agribusiness Cooperators Access to Credit from Formal Sources in Abia State, Nigeria, Agro-Science Journal of Tropical Agriculture, Food, Environment and Extension Volume 15 Number 2, pp. 23 - 28, 2016.
23. Ndiege B. O., Mataba L., Msonganzila M., Nzilano K. L., The link between financial performance and loan repayment management in Tanzanian SACCOS, African Journal of Business Management, 28 February, 2016, Vol. 10(4), pp. 89-97.

24. Onyeagoacha, S., Chidebelu S., Okorji E. Determinants of loan repayment of microfinance institutions in Southeast states of Nigeria. International Journal of Agricultural Management \& Development, 1(1), 4-9, 2012.

25. Ololade, R. A, Olagunju, F. I Determinant of access to credit among rural farmers in Oyo State, Nigeria. Global Journal of Science Frontier Research in Agriculture and Veterinary, (2013), Science. Vol.13 (2) Version 1.0, pp 17-21.

26. Oni O. A, Oladele, O. I and Oyewole, I. K. Analysis fo Factors Influencing Loan Default among Poultry Farmers in Ogun State, Nigeria. Journal of Central European Agriculture. Vol 6 No. 4 (619-624) July 20, 2005.

27. Santos C.M.C., Pimenta C.A.M and M.R.C.; Nobre, A estratégia PICO para a construção da pergunta de pesquisa e busca de evidências. Revista LatinoAmericana de Enfermagem, v.15, n.3, pp. 508-511, 2007.

28. Soubbotina, T. P.; Sheram, K. Beyond Economic Growth: Meeting the Challenges of Global Development; World Bank Publications: Washington, DC, USA, 2000.

29. Stephen Umamuefula Osuji Onyeagocha, Sunday Angus Nnachebe Dixie Chidebelu and Eugene Chukwuemeka Okorji. Determinants of Repayment of Loan Beneficiaries of Micro Finance Institutions in Southeast States of Nigeria. Strategic Journal of Business and Social Science. V 2(3): 167-175, September, 2012.

30. Ta Nhat Linh, Hoang Thanh Long, Le Van Chi, Le Thanh Tam and Philippe Lebailly. Access to Rural Credit Markets in Developing Countries, the Case of Vietnam: A Literature Review. Sustainability Open Access Journal. Vol 11, 1468, 9 March 2019.

31. Tonella P., Torchiano M., Du Bois M. and Systä T., "Empirical studies in reverse engineering: state of the art and future trends," Empirical Software Engineering, vol. 12, pp. 551-571, 10/01. 2007.

32. Katula R., Kiriinya S. Loan Repayment and Financial Performance of Deposit Taking Savings and Credit Cooperative Societies in Embu County, Kenya, International Journal of Current Aspects in Finance (IJCAF), Volume IV, Issue II, pp 102-118, May 2018. 